\title{
Kimya Tarihi Konusundaki Bir Kitap Üzerine Eleştiriler
}

\section{Ayten Koç Aydın, Onsekizinci Yüzyıl Osmanlıda Kimya. Editörler Melek Alpar ve Ümran Türkyılmaz. Ankara: Bilgin Kültür Sanat Yayınları, 2017. 131 s. ISBN-13: 978-605-9636-24-7.}

\author{
Emre Dölen ${ }^{1}$
}

'Prof. Dr., Marmara Üniversitesi Eczacıllı Fakültesi Emekli Öğretim Üyesi, İstanbul, Türkiye

ORCID: E.D. 0000-0002-3670-3627

Sorumlu yazar/Corresponding author:

Emre Dölen, Marmara Üniversitesi Eczacıllık Fakültesi Emekli Öğretim Üyesi, İstanbul, Türkiye

E-mail/E-posta: emredolen@gmail.com

Başvuru/Submitted: 21.04.2019 • Kabul/Accepted: 10.05.2019 • Online Yayın/Published Online: 03.07.2019

Atıf/Citation: Dölen, Emre. "Kimya Tarihi Konusundaki Bir Kitap Üzerine Eleştiriler" Osmanlı Bilimi Araştırmaları 20, 2 (2019): 157-162. https://doi.org/10.26650/oba.556556

Kitabın yazarı olan Doç. Dr. Ayten Koç Aydın, Dil ve Tarih- Coğrafya Fakültesi Felsefe Bölümü mezunu olmakla birlikte kimyaya ilgi duymuş, bu alanda eğitimi olmadığı halde yüksek lisans ve doktora tezleri yapmıştır. Daha sonra profesörlüğe yükseltilmek için bir kitap istendiğinde iki tezinin özetlerinin başına kimya tarihine ilişkin bir bölüm ekleyerek anılan kitabı yayınlamış ve profesörlüğe yükseltilmiştir. Gerek kimya ve gerekse Türk dili ile ilgileri bulunmayan Fransız Dili ve Edebiyatı doçenti Ümran Türkyılmaz ile Fransız Dili Eğitimi doçenti Melek Alpar'ın yaptıkları kaydedilen editörlüğün kitapta izini görmek mümkün değildir. Muhtemelen akademik performans puanı almaları için yazarın arkadaşı olan bu kişilerin adları editör olarak kitaba eklenmiştir. 


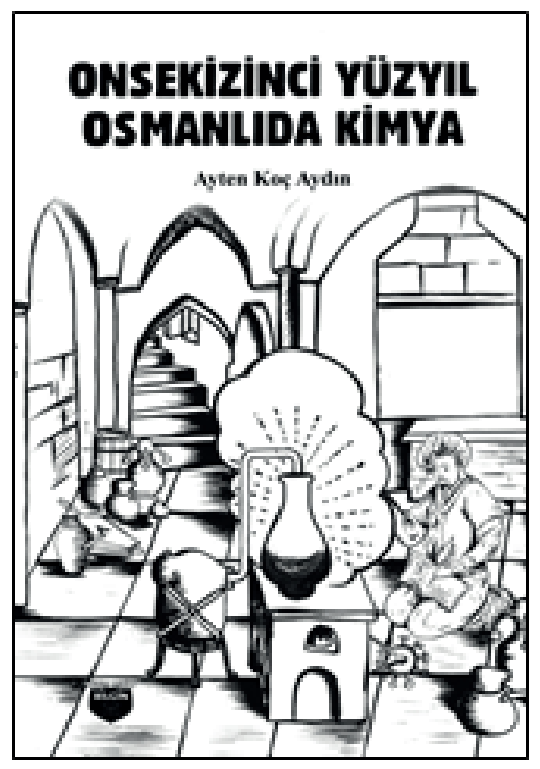

Tarafımızdan kitabın olumlu bir yanı görülemediğinden sadece eleştirmekle yetinilecektir. Kitabın tümünün ayrıntılı bir eleştirisinin hacmi, kitabın kendisi kadar olacağından ve bunun için büyük bir emek harcanması da gereksiz olduğundan, burada kitaptaki eksik ve yanlışlara örnekler vermekle yetinilecektir. Kitaptaki yanlışlar birkaç grup altında toplanabilir. Bunlar (1) Dil ve anlatım yetersizlikleri ile tekrarlar, (2) Terminoloji konusundaki yanlışlar, (3) Kavramlar ve bilgi konusundaki yanlışlar ve (4) Dipnotları ve kaynaklar konusundaki karmaşa olarak siralanabilir.

Dil ve anlatım yetersizlikleri ile tekrarlar: Kitapta çok sayıda düşük tamlama ve cümleler olduğu gibi anlamsız cümleler de vardır. Öncelikle kitabın adı düşük bir tamlamadır ve doğrusu “Onsekizinci Yüzyılda Osmanlı' da Kimya” olmalıdır. "Çinkoyu bir potada 1sıtarak metal çinko üretmişlerdir” (s. 15) gibi bir cümlenin ne anlama geldiğini anlamak mümkün değildir. "Mumya sargılarının üzerinde bir çiçekten elde edilmiş sarı boyalar bulunmuştur. Sarının çeşitli tonları için demir bileşiklerinden yararlanılmıştır” (s. 13) ifadesine göre sargıdaki boyalar bitkisel kökenli midir yoksa mineral kökenli midir?

Bilindiği gibi İyonya'da önce doğanın su, hava, ateş ve toprak gibi tek bir unsurdan oluştuğu düşüncesi ortaya atılmış ve daha sonra Empedokles tarafından doğanın tek bir unsur yerine bu dört unsurdan oluştuğuna ilişkin dört unsur teorisi ortaya konulmuştur. Bu teori önce Platon ve ardından Aristoteles tarafından yeniden biçimlendirilmiştir. Bundan bağımsız olarak tıp alanında hastalık nedenleri olarak beden sıvıları ortaya konulmuş ve bunlar da dört sıvıya indirgenmiştir, Bunlar arasındaki denge sağlığa ve dengenin bozulması da hastalığa karşılıktır ve tedavi yöntemi bozulan dengenin yeniden kurulması olmalıdır. Demokritos'un "insan bir küçük evrendir" ilkesinden yola çıkan Hippokrates bu iki teoriyi birleştirerek dört unsur - dört beden sıvısı (hılt) teorisini kurmuştur. Teori bundan sonra giderek gelişmiş, metalleri açıklamak için cıva, kükürt ve tuz ilkeleri eklenmiş ve bu haliyle hem kimya ve hem de tıp alanında geçerli olarak varlığını on sekizinci yüzyıl ortalarına kadar sürdürmüştür. Bu uzun zaman dilimi içinde teori herkes tarafından kabul edilmiştir. Yazar, bu gerçeği göz ardı ederek söz ettiği her kişi için (örneğin s. 26'da Câbir, s. 59 - 60'da Ali Çelebi, s. 88 ve 102'de Ömer Şifaî ve s. 112'de Abbas Vesim) bu teoriyi özetleyerek tekrarlamaktadır. Ayrıca yazarın açıklamalarından bu teoriye göre uygulanan tedavi yöntemini de tam olarak kavramamış olduğu anlaşılmaktadır. 
Terminoloji konusundaki yanlışlar: Kimyanın temellerinden biri adlandırma sistemidir (nomenklatür) ve bu sistem, eski çağlardan beri kimya ile ilgilenenlerin uğraşlarından biri olmuştur. Eski metinler üzerinde çalışırken en önemli sorun buralarda adı geçen maddelerin kimyasal karşılıklarının bulunması ve bu maddelerin adlarının da doğru yazılmasıdır. Aşağıda maddelerin adlarının ne kadar yanlış yazıldığına ilişkin bazı örnekler verilmiştir: "Sodyum carbonat" (s. 13) [karbonat olacak], "sodyum klorik [klorür olacak], potasyum klorik" [klorür olacak] (s. 5), "orpiment (arsenik sülfat [sülfür olacak])” (s. 35), "kükürt kurşunu” ve "yeşil sülfürik asit" [yeşil vitriol = demir(II) sülfat olacak] (s. 37). Bunların yanında tercüme yoluyla "altınlı magnezyum karbonat kükürtü” (s. 87), “cıvalı magnezyum taşı” (s. 98), "magnezyumlu damıtılmış sirke" ve "üçlü magnezyum tozu” (s. 99) gibi garip madde adları verilmiştir. Bütün bu maddelerin ne olduklarının çözümlenmesi gerekir. Ayrıca, magnezyum on dokuzuncu yüzyılda bir element olarak tanımlanıp magnezyum karbonat ile kalsiyum karbonat birbirinden ayırt edilebildiğine göre bu bileşik adlarındaki "magnezyum” sözcüğü nereden kaynaklanmaktadir?

Kavramlar ve bilgi konusundaki yanlışlar: Yazarın kimyasal teknoloji, simya, ilkel kimya (elkimya) ve modern kimya kavramlarının tanımları, bunların birbirlerinden olan farkları, aralarındaki sınırların nereden geçtiği konusunda yeterli ve net bir bilgiye sahip olmadığı görülmektedir. Buna rağmen yazar kitabın başında bilgi sahibi olmadığı kimya biliminin tarihinin nasıl yazılması gerektiğini tartışmaktadır. Yazarın yazılarının eksenini oluşturan ve kimyanın bir dalı gibi sunulan "iatrokimya” kimyanın bir dalı olmayıp tedavi yöntemine ilişkin bir tıp terimidir.

Paracelsus on altıncı yüzyılın ve Ömer Şifâî ile Ali Münşî de on sekizinci yüzyılın ilk yarısında yaşamışlardır ve aralarında iki yüz yıl fark vardır. Osmanlı hekimleri Paracelsus'u keşfedip ona sarıldıkları dönemde onun adı Avrupa'da neredeyse unutulmuştu. Bu iki yüz yıl içinde köprülerin altından çok sular akmış, atomculuk yeniden canlanarak Robert Boyle tarafından yaşama geçirilmiş ve modern element tanımı ortaya konularak modern kimyanın temelleri atılmıştır. on yedinci yüzyılın son çeyreğinden on sekizinci yüzyılın son çeyreğine kadar geçen yüz yıllık dönem modern kimyanın kuruluş dönemidir ama Osmanlıların bu gelişmelerden pek haberleri yoktur.

Yazar kimyasal ayırma yöntemleri, bunların temelleri, nerede ve nasıl uygulandıkları veya kullanıldıkları konusunda yeterli bilgiye sahip olmadığından sürekli yanlış ifadeler kullanmaktadır. Aşağıda bunlara bazı örnekler verilmiştir. "Maria, ... günümüzde hala (bainmarie) olarak kullanılan pişirme yöntemini bulan kişidir" (s. 21). Burada sözü edilen "pişirme" ile ilişkisi bulunmayan su banyosudur. Su banyosu sıvıların belirli sıcaklıkta veya $100{ }^{\circ} \mathrm{C}$ de 1sıtılması veya çözücülerin uçurulması için kullanılır. "Asetik asidin yoğunlaştırılması için sirke damıtılması" (s. 31) ifadesi Türkçe olarak düşük olduğu gibi (sirkenin olması gerekir) damıtma bir ayırma yöntemidir ve burada yapılan iş sirkenin damıtılması yoluyla asetik asidin 
yoğunlaştırılması değil ayrılmasıdır. "Buharlaştırma işlemi” (s. 95) süblimleştirme işlemidir. Sübimleşme bazı maddelerin katı halden doğrudan buhar haline geçmesi ve bu buharın da tekrar katı olarak yoğunlaşmasıdır. Ayrıca yazar solüsyon, eriyik ve çözelti terimlerini yan yana kullanmaktadır. Bu da muhtemelen alıntı yaptığı kaynaklar arasında terim birliği sağlayamamasından kaynaklanmaktadır.

"Metaller doğal hallerinin yanı sıra metal filizlerinin kimyasal işleme tabi tutulmalarıyla elde edilen bileşikleri olarak kullanılmıştır." (s. 12) Başlangıçta özellikle doğal metalik bakır toplanarak kullanılırken daha sonra metal filizlerinin kömür ile indirgenmesi ile metallerin bileşikleri değil metallerin kendileri elde edilmiştir. Altın ve gümüşün "kap-kacak yapımında ve süs eşyası yapımında kullanılması altın ve gümüş işçiliğinin gelişmesini, topraktan mekanik yollarla ayrıştırıldıktan sonra uygun miktarlarda kurşun, tuz ve kalayla karıştırılarak da kullanılması yöntemlerinin gelişmesini sağlamıştır.” (s. 12). Burada uygulanan işlem altın ve gümüşün çeşitli maddeler katılarak kullanılması olmayıp doğadan elde edilen altın ve gümüşün kupelasyon yöntemi ile saflaştırılmasıdır. "Belucistan'da polikron, kırmızı, siyah ve tekerlekle yapılmış çanak-çömlekler bulunmuştur. Çanakçömlek yapımında alçı, kum ve tekerlekte çömlek yapımın kolaylaştıran mika kullanılmıştır. Bunlardaki kırmızı renk demirin, siyah renk veya kahverengi renk hematitin mevcudiyetini gösterir" (s. 14). Burada sözü edilen "tekerlek” araba tekerleği olmalıp "çömlekçi çarkı"dır. Kırmızı rengi veren demir değil demir(III) oksit $\left(\mathrm{Fe}_{2} \mathrm{O}_{3}\right)$ ve siyah rengi veren de hematit yani demir(II,III) oksittir (FeO. $\mathrm{Fe}_{2} \mathrm{O}_{3}=\mathrm{Fe}_{3} \mathrm{O}_{4}$ ). "Cam yapımında zamk gibi organik maddeler kullanılmaktadır" (s. 14). Böyle bir ifade bütünüyle yanlış ve anlamsızdır. "Câbir'in hem maddî simya hem de manevî simya yönünde ilerleyen çalışmaları” (s. 33) ifadesindeki "manevî simya"nin ne olduğu belli değildir. "Yağlardan seyreltik sıvı" (s. 84) ifadesindeki konsantrasyonu düşük anlamına gelen "seyreltik" sözcüğü yerine "yoğunluğu daha düşük" teriminin kullanılması gerekir.

Çin uygarlığında “Bronz M.Ö. 1000 yıllarında demirle birlikte kullanılmıştır. Çin'de tunç yapımı yaklaşık M.Ö. 300’lerde görülmektedir” (s. 15) cümlesi yazarın “bronz” ile "tunç”un aynı bakır - kalay alaşımının farklı adları olduğunu bilmediğini ve bunları farklı iki madde sandığını göstermektedir. Yazar Van Helmont için "Görüşlerinin doğruluğunu kanıtlamak için boylamsal bir deney gerçekleştirmiştir” (s. 48) diye yazmaktadır. Böylece ben 50 yıldan fazla bir süre laboratuvarda deney yapmış bir kişi olarak deneylerin boylamsal ve enlemsel olarak ikiye ayrıldığını öğrenememişim. Bunların dışında belki bir de dönencesel deneyler olabilir. İfade bu kadar anlamsız olunca onun eleştirisi de ister istemez böyle oluyor.

Dipnotları ve kaynaklar konusundaki karmaşa: Örneğin dipnot 4 (s. 18), dipnot 12 ve 13 (s. 22) ile dipnot 133 (s. 81)'deki kaynaklar gibi dipnotlarda belirtilen kaynakların bir bölümü kitabın arkasındaki bibliyografyada yer almamaktadır Bazı dipnotlarında alışılmışın dışında bütün bir kitabı kapsayan [R. Boyle, The Sceptical Chemist, London 1661, s. 1 - 436] 
dipnotları verilmiştir. Ayrıca, bu kitabın adındaki "Chemist” sözcüğü "Chymist” olacaktır. Bazı dipnotlarda verilen kaynak ve sayfalar gerçeği yansıtmamaktadır. Örneğin 4 numaralı dipnotta (s. 18) "J. R. Partington, A History of Chemistry, London 1970, c. I" kaynak olarak verilip buraya gönderme yapılmaktadır. Daha ilerde s. 48 ve 49'da "Partington, a.g.e." denilerek yeniden göndermeler yapılmaktadır. Oysa burada I. cilt gibi gösterilen kaynak Partington'un kitabının 1961'de yayınlanmış olan II. cildidir. Ayrıca, 53. dipnotta (s. 48) belirtilen ve Partington'un II. cildi olan kaynağın 222. sayfasında Van Helmont'un söğüt ağacı deneyinden söz edilmemektedir. Gene burada 56 numaralı dipnotta belirtilen konu kaynağın 343. sayfasında olmayıp 341 ve 352 - 353. sayfalarında yer almaktadır. Bunların yanında 71 ve 72 numaralı dipnotlarda (s. 64) belirtilen kaynağın [Partington, a.g.e.. c. I, s. V] zikredilen sayfasında metindeki konu ile ilgili bir bilgi söz konusu değildir. Kitabın arkasındaki "Kaynaklar"ın yazar adına göre mi yoksa soyadına göre mi düzenlendiği belli olmayıp ikisi birbirine karışmıştır. Bazı kitap adları eksik veya yanlıştır. Örneğin, Cevat İzgi'nin kitabının adı "Osmanlı Medreselerinde Bilim" değil Osmanlı Medreselerinde İlim'dir. "Crosland, Mauricio P., Historical Studies in Chemical Terminology" adlı kaynakta yazarın adı "Mauricio" değil "Maurice" olduğu gibi kitabın adı da "Historical Studies in the Language of Chemistry"dir ve bu kitap Zeki Tez tarafından Kimya Dili Üzerine Tarihsel Incelemeler adı altında Türkçeye çevrilmiştir. (Nobel Yayınları, Ankara 2000). Yazar bu çeviriyi iyice inceleseydi terminoloji konusunda düştüğü hataların en azından bir bölümünden kurtulabilirdi. Kaynaklardaki Holmyard, E. J., Alchemy, Great Britain, 1968” biçimindeki künye "Holmyard, E. J., Alchemy, Harmondsworth: Penguin Books, 1968" olmalıdır. Gerek dipnotlardaki ve gerekse kaynaklardaki eksiklik ve düzensizlikler yazarın bizzat görmediği bazı kaynakları başka yerlerden aktararak metne eklediği kanısını uyandırmaktadır.

Kimya tarihi konusundaki kitaplar on dokuzuncu yüzyıl ortalarından itibaren yazılmaya başlanmış ve günümüzde de yazılmaya devam edilmektedir. Kimya tarihi ile ilgilenen bir kişi olarak bugüne kadar kimyacı olmayan bir kişi tarafından yazılmış bir kimya tarihi kitabına rastlamadım. Çünkü böyle bir kitabı yazabilmenin ön koşulu kimya bilgisine sahip olmaktır. Kimya çok özel bir bilim alanıdır ve onun tarihi ile uğraşmak demek eski metinlerdeki işlemleri çözebilmeye ve sözü edilen maddelerin neler olduğunu saptamaya dayanır ve bunun için de kimya eğitimi almış olmak ön koşuldur.

Uzun yıllar önce Prof. Dr. Esin Kâhya ile yaptığım bir görüşmede bana "Bir kız var, onunla kimya tarihi çalışıyoruz" dediğinde ben de "Bir kimyacı mı buldun?" diye sorunca bana "Hayır, Felsefe mezunu ama Fen Fakültesi’nden bir Genel Kimya dersi aldı" cevabını vermişti. Ben de kimyacı olmayan birisinin eski kimya metinlerinin içinden çıkamayacağını belirtmiştim. Yıllar sonra benim ne kadar haklı olduğum ortaya çıkmış bulunuyor. Burada yaptı̆̆ımız eleştirilerin çok daha fazlasını yazarın yüksek lisans ve doktora tezlerine de yöneltmek mümkündür. 
Yazar, Giriş bölümünde "Kitap, sonraki çalışmalar açısından ilham verici olması umuduyla, on sekizinci yüzyıl Osmanlı tıbbının içine yerleşmiş olan kimya unsurlarını ortaya çıkarma, ayrıştırma ve modern kimya öncesi dönemde Osmanlı kimyasının seyrini ortaya koymaya yönelik bir denemedir" (s. 7) demektedir. Burada "Osmanlı kimyası"nın anlamı nedir? Eğer varsa, Osmanlılar tarafından geliştirilerek ortaya konulmuş olan kimya bilgisi Osmanlı kimyası olarak anılabilir. Böyle bir şey olmadığına göre "Osmanlılarda kimya bilgisi” denilmesi gerekir. Kitap "ilham verici olması” bir yana, içerdiği yanlışların çokluğu ile bir "bilgi kirlenmesi" meydana getirmektedir. 